\title{
Scripta
}

Revista Internacional de Literatura i Cultura Medieval i Moderna

\section{Leriano y Llull: de amantes y caballeros}

\author{
Leriano and Llull: on lovers and knights
}

\author{
Antonio Cortijo Ocaña \\ amcortijo@aim.com \\ University of California - Santa Barbara
}

\begin{abstract}
Resumen: En sus últimas palabras con Tifeo antes de cometer suicidio por amor en la Cárcel de Amor, Leriano tiene una oportunidad perfecta para atacar a su desdeñosa dame sans merci, Laureola. Pero Leriano está a la altura de las circunstancias y hace una exposición de amore ante su amigo, que debe mucho al Libro de la orden de la caballería de Llull, un libro destinado a tener importancia capital en la época tardomedieval y del primer Renacimiento.
\end{abstract}

Paraules clau: Diego de San Pedro, Carcel de Amor, Llull, Libro de la orden de la caballería, Leriano

\begin{abstract}
In his last words with Tifeo before committing suicide in Cárcel de Amor, Leriano has a perfect opportunity to attack his disdainful dame sans merci, Laureola. But Leriano raises above the circumstances and makes and exposition de amore to his friend which in greatly indebted to Llull's Book of the Order of Chivalry, a book that was destined to acquire paramount importance in late medieval and early modern Europe.
\end{abstract}

Keywords: Diego de San Pedro, Cárcel de Amor, Llull, Libro de la orden de la caballería, Leriano 
El propósito de estos breves apuntes es comentar el final de la Cárcel de Amor de Diego de San Pedro a la luz de un texto del Llibre de l'orde de cavalleria de Llull. Leriano, que ha sido rechazado como amante por Laureola, está a punto de cometer su mayor acto de sacrificio amoroso, sufriendo una pasión que remeda la de Cristo y cometiendo un suicidio por amor. Se dejará morir de inanición, no sin antes romper las cartas que se ha cruzado con su amante y mezclarlas en un cáliz con agua, bebiéndolas como si se tratara de una consagración y comunión eucarísticas. Laureola, en la última ocasión que tiene de parlamentar con su amante, le ha rechazado por imperativos de su honra, es decir por una motivación social que nada tiene que ver probablemente con sus sentimientos amorosos hacia Leriano. Abatido y despechado, Leriano reflexiona con Tefeo, que ve en la actitud de Laureola un ejemplo paradigmático de la actitud general de la mujer en materia amorosa: «... para favorecer su habla trajo todas las razones que en difamación de ellas pudo pensar, creyendo por allí restituírle la vida». Leriano se resiste a atacar a Laureola o a deducir de su comportamiento las conclusiones anti-fémina prototípicas de la querelle des femmes de la época a que parece conducirle el parlamento de Tefeo. Es más, se siente en la obligación de darle una lección a éste («te será más provechoso enmendarte por mi contradicción») con una expositio detallada de su visión femenina.

Es esta expositio la que me interesa para estas notas. A mi entender la construcción del discurso de Leriano se basa sobre una discusión no sólo sobre el amor, sino sobre la caballería de amor, y retrata en ella un modelo ideal de amante cortesano y caballeresco. En ella, Diego de San Pedro, opino, debe mucho a un texto que se había convertido en modélico para la descripción o definición de la caballería, el Llibre de l'orde de cavalleria de Raimundo Lulio, que a su vez contenía la herencia (en materia caballeresca) de las Siete Partidas alfonsíes, el capítulo 112 del Llibre de contemplació en Déus del propio Llull, varios textos patrísticos sobre la alegoría de las armas del cristiano y el famoso texto sobre la caballería (del Temple) de san Bernardo (el De laude novae militiae ad milites Templi liber). ${ }^{1}$ Amén de las fuentes que ya se han citado para este episodio (ver infra), no sería descabellado pensar en estas lecturas para un autor que está asociado a la corte de los Reyes Católicos y los círculos aristocráticos del momento, donde el debate de la caballería era de sobra conocido. ${ }^{2}$

Entre las quince causas que Leriano lista «por que yerran los que en esta nación ponen lengua [contra las mujeres]», la séptima reza así:

La séptima es porque cuando se estableció la caballería, entre las otras cosas que era tenido a guardar el que se armaba caballero era una que a las mujeres guardase toda reverencia y honestidad, por donde se conoce que quiebra la ley de nobleza quien usa el contrario de ella. ${ }^{3}$

1S. Bernardi Abbatis, De laude novae militiae ad milites Templi liber, J. P. Migne ed., Patrologiae cursus completus. Series latina, Parisiis, Apud Garnier, 1841-1855, vol. 182, cols. 0921A-0929B.

2 Damos al final de estas notas un resumen detallado del libro de Llull, siguiendo el que incluíamos en nuestra traducción al inglés y español de Ámsterdam, John Benjamins, 2015 (The Book of the Order of Chivalry). https:// benjamins.com/\#catalog/books/ivitra.8/main.

3 Cito por la versión modernizada de http://www.ciudadseva.com/textos/novela/carcel.htm. 
De modo semejante, en II.19 Llull afirmaba que

el oficio de caballero consiste en defender viudas, huérfanos y desvalidos. Pues así como es costumbre y razón que los mayores ayuden a defender a los menores y los menores encuentren refugio en los mayores, así es costumbre de la orden de caballería que, por ser grande y honrada y poderosa, vaya en socorro y ayuda de los que le son inferiores en honor y fuerza. (traducción mía) $)^{4}$

Y dos secciones más abajo Llull amplificaba su opinión:

Si la caballería, que es oficio tan honrado, consistiese en un oficio de robar y de destruir a los pobres y a los desvalidos, y de engañar y de forzar a las viudas y otras mujeres, entonces sería bien grande y noble el oficio de ayudar y mantener a huérfanos y viudas y pobres.

Volviendo al texto de la Cárcel, la segunda sección de la expositio de Leriano contiene veinte razones «por que los hombres son obligados a las mujeres». La crítica ha señalado que en la base de las mismas puede percibirse la huella del tratado en Defensa de las virtuosas mijeres de Diego de Valera. Sin embargo, dentro de un contexto homilético y de prescripciones sobre la caballería, es decir dentro del tratamiento de las virtudes cardinales y teologales en el esquema de definición de la caballería, el ejemplo quizá más difundido en el siglo XV por toda Europa es sin duda el que se encuentra en Llull. Al encomendarse al amor de las mujeres éste hace más prudentes y más justos a los enamorados. Especial relevancia tienen estas dos virtudes (prudentia y iustitia) a la vista del discurso sobre la iustitia presente en Llull:

La segunda razón es porque de la virtud de la justicia tan bien nos hacen suficientes que los penados de amor, aunque desigual tormento reciben, hanlo por descanso, justificándose porque justamente padecen. Y no por sola esta causa nos hacen gozar de esta virtud, mas por otra tan natural: los firmes enamorados, para abonarse con las que sirven, buscan todas las formas que pueden, de cuyo deseo viven justificadamente sin exceder en cosa de toda igualdad por no infamarse de malas costumbres. (II.8)

Al comentar esta virtud Llull decía también de ella lo siguiente:

La prudencia es una virtud por la cual el hombre tiene conocimiento del bien y del mal, y por la que tiene conocimiento para ser amante del bien y enemigo del mal. Asimismo la prudencia es ciencia por la cual el hombre tiene conocimiento de las cosas futuras por medio de las cosas presentes, y hay prudencia cuando el hombre sabe esquivar los daños corporales y espirituales por medio de algunas precauciones y conocimientos. Por esto, como los caballeros existen para perseguir y destruir a los malos, y como ningún hombre se mete en tantos peligros como los caballeros, ¿qué cosa le es más necesaria al caballero que la prudencia? (II.9) 4 Se cita el texto de Llull traducido al castellano de mi edición de Ámsterdam, John Benjamins, 2015 (The Book of the
Order of Chivalry). 
Y aun antes, en el mismo párrafo, la hacía sostener el edificio entero de la caballería:

La justicia debe ser mantenida por los caballeros, porque, así como los jueces tienen el oficio de juzgar, igualmente los caballeros tienen el oficio de mantener la justicia. (II.9)

San Pedro en la Cárcel presta en su docena razón particular atención a la liberalidad («libertad»), también llamada «franqueza»,

que como largamente nos hacen depender lo que tenemos, somos alabados y tenidos en mucho amor, y en cualquier necesidad que nos sobrevenga recibimos ayuda y servicio. Y no sólo nos aprovechan en hacernos usar la franqueza como debemos, mas ponen lo nuestro en mucho recaudo, porque no hay lugar donde la hacienda esté más segura que en la voluntad de las gentes.

Llull en su tratado de caballería menciona la largueza hasta tres veces, especialmente relevante en II.14 («Y cuando sea menester, que tenga largueza con sus manos y haga gasto y dé según corresponde a su honor, y que sea valiente y no tema a sus enemigos, y que, cuando tema herir, deje la flaqueza de ánimo») y II.15 («por esto el caballero está deseoso de tener bienes ajenos y es perezoso para ganar bienes semejantes por fuerza de armas. [..].] [Y] por eso la envidia le hace pensar cómo poder hacer engaños y falsías. Por falta de fortaleza, cuando ésta no está en el corazón del caballero, la envidia echa del corazón a la justicia, caridad [y] largueza»). Pero de mayor interés es esa asociación de San Pedro entre largueza y liberalidad con franqueza, que se asocia igualmente con la condición de libertad-liberalidad:

La docena razón es porque apartándonos de la avaricia nos juntan con la libertad, de cuya obra ganamos las voluntades de todos.

En un contexto semejante y con ese significado el vocablo aparece en varias ocasiones en Llull. Así, en VII.3 se lee que

la caballería y la franquicia se avienen entre sí, y la franquicia y el señorío del rey o príncipe [también] se avienen. Por ello conviene que el caballero sea libre, para que el rey [y] príncipe sea señor. Y siendo esto así, por ello conviene que el honor del rey o de cualquier [otro] señor se avenga con el honor del caballero de tal modo, que el señor de la tierra sea señor y el caballero sea honrado.

En este último caso aparece a su vez como eco de su tratamiento en las Siete Partidas, en la adición al título XXI, ley III:

En las ordenanças reales libro .iiij. titulo .ij. larga mente fabla de los fidalgos commo les deuen ser guardadas sus libertades \& franquezas que tienen de los reyes por la grand bondad que dios en ellos puso... 5

5 Cito por P. Sánchez-Prieto Borja, Rocío Díaz Moreno, Elena Trujillo Belso eds. Las Siete Partidas. Alfonso X el Sabio. Edición de textos alfonsíes en REAL ACADEMIA ESPAÑOLA: Banco de datos (CORDE) [on-line]. Corpus diacrónico del español. http://www.rae.es. 
Ya para concluir, Leriano informa a Tefeo que son muchas más las razones para obligarse a las damas («lo mucho que a esta nación somos los hombres en cargo»), pero no quiere dejar de mencionar una última, que pone de nuevo todo su discurso del amante en el contexto adecuado de comprensión: el del medio cortesano-aristocrático de renovado ideal caballeresco del siglo XV al que el autor pertenece (así como su personaje, Leriano):

Diversas razones había para mostrar lo mucho que a esta nación somos los hombres en cargo, pero la disposición mía no me da lugar a que todas las diga. Por ellas se ordenaron las reales justas, los pomposos torneos y las alegres fiestas; por ellas aprovechan las gracias y se acaban, y comienzan todas las cosas de gentileza.

Claro está que Diego de Valera, fuente mencionada por la crítica para este episodio de la Cárcel, podría haber prestado a San Pedro muchas notas para este episodio, en particular procedentes de su Tratado de los rieptos e desafios que entre los cavalleros y bijosdalgo se acostumbran hazer, según las costumbres de España, Francia e Inglaterra, en el qual se contienen quáles y quántos son los casos de traición e de menosvaler e las enseñas e cotas d'armas (1458-1467), de su Breviloquio de virtudes y, especialmente, de su Espejo de verdadera nobleza (San Pedro, Parrilla ed.). No obstante, no se cierra aquí sin más el asunto de las fuentes del último episodio de la Cárcel, pues los ecos son a veces tan importante como los textos fuente.

Con el Llibre de l'orde de cavalleria Llull acomete a fines del siglo XIII (entre 1274 y 1276) un verdadero programa de transformación de las órdenes caballerescas. El libro parece una amplificatio del capítulo 112 de su Llibre de contemplació en Déus, donde había realizado una crítica feroz a la (mala) caballería. Como ya hemos indicado en nuestra traducción al inglés y español del texto antes mencionada,

Llull devotes his little treatise or doctrinal handbook to the definition of the duties of a perfect knight, that is the religious and moral values that one should ascribe to the practice of knighthood. In addition, he is also interested in delving into the religious and moral aspects of chivalry as well as in trying to reform this institution (Lloret, Carreras y Artau 1934, Costa 1997). His intention is to join together the concepts of Church and Chivalry and to construct a personal ethic based on the Christian faith. The book, didactic and moral in nature, examines the origin and nobility of chivalry and the ethical foundation of the knight's profession, which ultimately lies in the defense of the Christian faith.

El caballero representa para Llull la incardinación del esfuerzo humano para conseguir una quies permanente con su Creador, misión que tiene consecuencias tanto temporales como especialmente espirituales. De hecho, uno de los aspectos remarcados por la crítica al analizar el tratado caballeresco de Llull consiste precisamente en esa conjunción de los valores de caballería temporal y milicia cristiana que aporta novedad al tratado luliano al enfatizar los valores morales del caballero. Si el hombre debe mantener una batalla constante consigo mismo y con el mundo, permanciendo en estado constante de certamen, está con ello en un eterno estado de ansiedad en la medida que siempre intenta superar y vencer su condición de invalidez moral. Mediante el desarrollo de la ira justa el caballero canaliza su fortaleza hacia el propósito de la prudencia y justicia. 
La fortuna del tratado luliano fue inigualable a partir de su composición, y existen numerosas copias que lo atestiguan. De hecho, vino a ser considerado el tratado par excellence sobre la caballería en la Edad Media, en particular durante el siglo XV. Además de los numerosos mss. con traducciones francesas e inglesas, William Caxton realizó una versión al inglés que se editó con el título de Book of the Ordre of Chivalry or Knyghthode (Westminster: W. Caxton, 1483-1485). No es difícil sospechar que San Pedro tuviera conocimiento del mismo, amén de haber experimentado su presencia en otros tratados caballerescos o textos sobre la nobleza que son herederos de la obra luliana.

Leriano enmarca su discusión final con Tefeo en el mismo marco en que Llull situaba la caballería. La conjunción de valores temporales (defensa de las virtudes) no sólo es indisociable de la defensa de las mujeres, sino que el enamorado cortés se enmarca dentro del contexto de la caballería. Pero ésta a su vez se escinde en un par complementario en el que insiste toda la escena de Leriano y Tefeo: caballería de amor y caballería espiritual. No en vano Whinnom ya definiera a Leriano «amante ideal y perfecto caballero» (69). Así se podría interpretar la asociación de Leriano con Cristo como la de un miles Christi que sigue o imita al maestro, y del mismo modo se podría considerar la muerte por amor de Leriano como una muerte pasional (passio Leriani), insistiendo en la imagen sacroprofana del amor que también se había difundido en numerosas composiciones poéticas cancioneriles contemporáneas. Pero insistimos, es la especial vinculación de este episodio de la Cárcel de Amor con la idea de la caballería la que me resulta ahora de especial interés, y donde mejor aparece reflejada es en el texto de Llull del que beberán después muchos otros tratados caballerescos.

Otra obra que sí guarda similitudes con la temática amorosa de la Cárcel en este contexto del caballero de amor, aunque enmarcada en un género distinto, es el Tirant lo Blanch. La crítica ha remarcado el influjo del Llibre de l'orde de cavalleria luliano en la novela caballeresca de Martorell, con Hauf, Ramos y Alemany \& Martos a la cabeza, entre otros. Estos estudiosos han señalado que la llamada sección inglesa de la obra de Martorell contiene una subsección dedicada a la orden de caballería (capítulos 28-39), que a su vez debe mucho al Prólogo y los capítulos I y IV del tratado caballeresco de Llull. A Tirant le enseña un ermitaño sobre asuntos caballerescos como en el Llibre de l'orde de cavalleria, que, entre otras cosas, le hace saber sobre el valor alegórico de las armas como en el tratado luliano. ${ }^{6}$

En la obra de San Pedro el contexto caballeresco a lo roman es muy claro. Tras el enamoramiento inicial, declaración y aceptación por parte de Laureola, Persio, rival de amores de Leriano e hijo del señor de Gavia, difunde rumores que atentan contra la honra de la dama. Leriano le desafía y vence en dos ocasiones. Pero el rey Gaulo, padre de Laureola, confiando en los rumores, condena a su hija a muerte. Tras liberar a la doncella y huir con ella, los ejércitos de Gaulo se enfrentan a Leriano y los suyos en una batalla enconada. Convencido al fin de la falsedad de la acusaciones, Gaulo perdona

6 También la titulada Stòria de Jàson i Medea del valenciano Joan Roís de Corella parece deber mucho al tratado luliano en su concepto de la caballería basada en el ejercico de la virtud, todo ello opuesto a las prácticas caballerescas que privilegian la fuerza, como indica Corella. 
a su hija, pero Laureola quiere defender su honor y no aumentar las sospechas sobre su actuación y comportamiento en un futuro, de modo que se ve obligada a rechazar a Leriano en el último episodio de la novela. En este contexto ciertamente de novela caballeresca en que se intercambian cartas de amor, como en el Tirant, es donde nos encontramos con el sermón final de Leriano, como alguna crítica ha tildado su defensa de la mujer final. Leriano, en vista de estos paralelos genéricos, no solo es un enamorado sentimental sino un héroe caballeresco de novela en quien se unen de manera indisociable amor y caballería. Y en función de esta última, el texto de Llull se muestra pertinente para la interpretación y comprensión de la Cárcel de Amor.

Dos breves notas me servirán aún más para reforzar la vinculación de esta última con el tratado caballeresco de Llull. En efecto, la crítica ha resaltado que en él deben remarcarse su carácter homilético y alegórico (con su largo episodio sobre la alegoría de las armas, en este último caso heredero de varios textos bíblicos y patrísticos, y especialmente del De laude novae militiae ad milites Templi liber de San Bernardo). Las armas del caballero se interpretan en esta corriente como valedoras temporales del hombre en paralelo a la defensa que al mismo le procuran las virtudes. Así, insistiendo en esta visión temporal-espiritual de las armas del cristiano, a cada arma en concreto (casco, loriga, espada, etc.) le corresponde una asociación particular con alguna de las siete virtudes. De entre ellas, claro, la más relevante es la concordancia entre la espada y la justicia, de base bíblica.

Asimismo, el tratado luliano se ha interpretado como una suerte de homilía ad extra sobre la caballería dirigida a una audiencia laica (la casta caballeresca) (Fallows, Introduction): ${ }^{7}$

This idea had already been anticipated in the first paragraphs of ch. 112 of the Llibre de contemplació en Déu. In fact, in his Liber de praedicatione and Ars brevis praedicationis Llull put forward a new homiletic system through the writing of sermons per moralem philosophiam, a sort of moral instruction for Christians which was not necessarily based on biblical texts. If Christians could understand their faith, they would be more virtuous. This principle seems to apply to the writing of Llull's book on chivalry.

Pues bien, Leriano diserta sobre el amor en un contexto homilético y religioso en que su propia figura se parangona con la de Cristo. Todo ello tras el rechazo sufrido por parte de su enamorada, es decir, cuando está en esa situación de lucha y certamen de resonancias paulinas. Como han indicado Serés y Cortijo, el concepto de militia vitae tiene tanto orígenes filosóficos como bíblicos. Séneca nos recuerda (o lo hace a Lucilio) que «vivere militare est» (Epist. XCVI), como también hacen Job («militia est vita hominis super terram») (8:1) y especialmente san Pablo. Este último se refiere a su lucha, espiritual y física, como un «bonum certamen certavi, cursum consummavi, fidem servavi» (2 Timoth.4:7). Leriano llega al final de su vida tras haber cumplido con el dictum paulino, según él mismo se imagina en su discurso. Es, pues, en su mente un miles christianus, un miles Christi, un enamorado que se ve como caballero y como caballero cristiano. Esta conjunción

\footnotetext{
7 «Fallows interprets it ingeniously as a homiletic primer «to enable clerics to teach [knights], and a chivalric textbook to enable knights to learn» (5).
} 
de milicia temporal (amorosa) y milicia espiritual es de la misma índole que la predicada por Llull en su tratado caballeresco y repetida luego hasta la saciedad en sermones y tratados de caballería que siguen su modelo. Podría, sin duda, pensarse que todo este episodio es paródico, y que burla burlando San Pedro se aprovecha de este marco caballeresco y amoroso cortesano reconocible para sus lectores con el objeto de parodiar el amor cortés y dejarnos saber de la inanidad y absurdo de su construcción como modelo de comportamiento y sobre todo de la imposibilidad de su puesta en práctica en el contexto de la sociedad contemporánea. En cualquier caso, no se invalida la presencia del modelo luliano en la obra.

Cuando, acabada la expositio de Leriano, sale a escena su madre, a punto aquél de cometer su último sacrificio amoroso, la caballería espiritual de Leriano queda incluso más reforzada. La madre aparece como una Dolorosa que remeda el postramiento ante la Cruz de su hijo moribundo. La imagen, que está dotada de la fuerza emotiva y el pathos de la Vita Christi del Cartujano y de los textos herederos de ella, nos recuerda la versión de Sor Isabel de Villena (calificada por la crítica de auténtica Vita Virginis Mariae), con esa insistencia en la fuerza emotiva del amor a través del alma femenina. Esta escena final en la Cárcel no hace más que servir de perfecto complemento al papel de Laureola en la obra y hasta del contenido mismo del último sermón de Leriano. Su madre sería así otro ejemplo más (o quizá el más excelso) de las virtuosas mujeres que Leriano ha incluido en su catálogo. Pareciera así que Leriano está dando a entender que a ellas toca experimentar el mayor dolor de la relación amorosa que no llega a buen término. En este sentido, y haciendo una prolepsis, pareciera que entre Leriano y Laureola puede verse una dicotomía de conceptualizaciones del amor semejante a la famosa disputa entre Grisóstomo y Marcela en el Quijote. Pero Leriano no actuará como aquel, que deja de ejercer una recomendable ira justa y da rienda suelta a su desesperación en un discurso que solo insiste en su narcisimo y soberbia. Leriano, por contra, encauza su final último dentro de uno de los posibles parámetros que le permitía el código amoroso cortesano, a pesar de las reconvenciones in contrario de Laureola, que recuerda la inanidad de su acto. 


\section{Apéndice I}

\section{Prologue}

Llull divides his book into seven parts that signify the perfection and order of the cosmos as represented by the image of the seven planets. He begins by creating a fictional story that resembles a romance. A knight who had upheld with great nobility and courage his office of knighthood decided to abandon the temporal world and retire to a secluded hermitage in a forest, surrounded by an idyllic landscape of water and trees, a sort of paradisiacal hortus conclusus. There he devoted himself to contemplating and praying to God. A squire happened to arrive in this forest and let the knight know that he was going to a king's court with the intention of being dubbed as a knight. The knight is surprised to know that the squire seeks knighthood but does not know what the Order of Chivalry consists of. To remedy this, he lends the squire a book which he possesses and frequently reads to «remember the gracious mercy that the Lord has shown me in this world because I have honored and upheld the Order of Chivalry with all my might.» Once the squire finished reading it, he understood that it was composed to restore the devotion and loyalty that must be observed by the knight, and comes to know

that a knight is a man chosen among thousands to hold the most noble office of them all. (I, 10)

The knight then asks the squire to spread the message of the book by taking it to the king's court and showing it to all the knights-to-be.

The story resembles the biblical narrative of the master and disciple, as well as numerous medieval romans and stories based on the wise hermit motif who instructs the hero.

\section{Section I: On the Beginning od Chivalry}

Based on the biblical narrative of sin and redemption, this section begins with the story of human frailty and failure (sin) and the restoration of justice or order from chaos. As a result, charity, loyalty, justice and truth were reinstated. It also reminds us of the biblical creation narrative and the subjection of nature and animals to man. As the horse was the noblest animal, it was given to man to serve him, as were the noblest weapons. The knight must have courage and good breeding and must be loved and feared by people. The knight is considered the noblest and the chosen person to reinstate justice; in return he is obliged more than others to be good to God and the people. The knight is given a squire whom he teaches and by whom he is served and accompanied in his feats of arms. The knights profess their Order through noble valor and the 
force of arms. Through the knights men fear to commit offences just as they learn to love God through clerics. «It would be most appropriate that a member of the Order of Chivalry found a school to teach it, writing books about it and teaching it as an art, just like the other sciences are taught, so that the sons of knights could learn the science that pertains to Chivalry and could later become squires and then wander the world with the knights» (I, 14).

\section{Section II: On the Office that Pertains to the Knight}

Knighthood consists of defending the Catholic Faith and conquering the infidels who are intent upon destroying the Church. Because the noblest offices in the world are those of cleric and knight, there should be the greatest friendship between them, as well as respect and love among all the Orders. Knights should have seigneury as well as lording over land. The social pyramid must include emperors, kings, counts, viscounts and the rest of the chivalric ranks, and knights should defend his temporal lord. The knight's duty is to defend justice. Knighthood resides both in strength of body and of soul. Therefore, the knight should practice riding, jousting, fencing, hunting for the training of his body, as well as virtues (justice, wisdom, charity, loyalty, truth, humility, fortitude, hope, etc.) for that of his soul. Chivalry as an Order cannot be unmade by any king. Chivalry is supported by valor as well as by wisdom and common sense. The knight must defend widows, orphans and the infirm, as well as protect the roads and cities and defend peasants against thieves and traitors. Chivalry acquires honor through loyalty, courtesy, liberality and piety. Larcenous, treacherous and thieving knights dishonor Chivalry, and so do knights who are perjurers, arrogant and unchaste. Justice is in accord with humility and particularly with peace.

\section{Section III: On Examining the Squire Who Wishes to Join the Order of Chivalry}

The next two sections focus on the squire. Knighthood should be restricted to few. The squire will be required to be of suitable age and come from noble lineage. He must have noble habits and perform noble deeds. The squire will be asked if he loves and fears God, what are his habits, and he will be required to have nobility of courage. This nobility of courage lies not in the mouth or in vainglory, but in faith, hope, charity, justice, fortitude, loyalty, etc. He should be asked about the reasons why he wants to become a knight (not to be rich and rule without honoring knighthood) and should be examined about his past actions. He should understand clearly the difficulty inherent in the profession of the knight and the great perils that await him. He should have sufficient wealth, a horse and harness and lack physical defects. Pride, avarice, disloyalty, sloth, ire, gluttony, etc. disqualify a squire from becoming a knight. 


\section{Section IV: On the Way in Which the Squire Shall Receive Knighthood}

The squire will be accepted into knighthood through the mediation of a spiritual knight (priest) and a temporal knight. The squire must be dubbed a knight on an important feast day, on whose eve he must fast, keeping a vigil devoted to prayer and meditation on God and the Order of Chivalry. He must also confess his sins. The next day he should attend solemn mass, walk up to the altar and present himself to the priest and to the Order of Chivalry. The sermon should be devoted to the fourteen articles of faith, the ten commandments and the seven sacraments and other topics alike. The knight in charge of dubbing the novel knight, as well as the priest, must be virtuous and flawless, for otherwise knighthood itself is debased. The squire then kneels in front of the altar and lifts his hands and spirit to God; then the knights girds the sword upon the squire (meaning justice and chastity), kissing him and slapping him (meaning the burden taken by the new knight). At this point the squire mounts his horse and presents himself to the people. A festival then follows with banquets, tournaments and the exchange of gifts.

\section{Section V: Meaning of the Knight's Arms}

This section is the central and most relevant part of the book as indicated by its placement in the middle of the book (there is almost the same number of pages before and after section V). Llull establishes a connection between spiritual and temporal chivalry through an allegorical explanation of the knight's and his horse's armor and accoutrements (Johnston, Fallows 8 et ss.). ${ }^{8}$ The section describes the knight's armor from head to toe, following a well established rhetorical Classical and medieval literary construction. It begins with the echo of a Biblical image describing the allegorical meaning of the sword, which he associates to the knight's main purpose, that is defending justice (see Appendix II for more details). There follow connections between lance and truth, helmet and shame to be obedient to the Order of Chivalry, hauberk and a castle and rampart against vices, the sollerets and the safekeeping of roads, spurs and diligence and honoring the Order of Chivalry, gorget and obedience to the Order, mace and bravery or courage, mercy and hope in God to combat enemies, shield and knighthood's stand between king and people, saddle and firmness and valor in battle, horse and nobility of spirit. The horse's accoutrements are described in the next section, and allegorical connections are once again established between the bit and the knight's generosity, daring, and courage; the shaffron and thejust war, bardings or accoutrements and sufficient wealth to uphold Chivalry honorably, the purpoint or gambax and perseverance to endure travails for Chivalry's sake. Finally, Llull discusses other elements of the knight's paraphernalia such as the blazon of the shield and the standard, which he connects to courage and the upholding of the knight's lord's honor and property.

8 For an analysis of medieval weaponry, see Blair, Fallows 2010, Hoffmeyer, Nicolle, Pyhrr and Soler del Campo.

SCRIPTA, Revista internacional de literatura i cultura medieval i moderna, núm. 5 / juny 2015 / pp. 1- 20 


\section{Section VI: On the Habits that Pertain to the Knight}

The nobility of courage must be also accompanied by nobility of habits and good manners that are built upon the seven virtues. Through faith the knight acquires hope, charity and loyalty and on account of it they travel to the Holy Land and participate in Crusades. Through hope the knight remembers God in his trials and tribulations and acquire strength and courage. Through charity the knight is without cruelty and ill will, lightening the burdens of his profession. Justice is essential to the knight and without it a knight deserves to be demoted. Through prudence the knights acquires knowledge of good and evil and avoids bodily and spiritual harm. Through fortitude the knight is endowed with courage to fight against the seven deadly sins. Gluttony is a vice of excess that begets idleness and frailty. Lust engenders overindulgence, falsehood, treachery, injustice, etc. in a knight. Avarice subjects courage to evildoing, covetousness and avarice. Through sloth the knight seeks evil and rejects good, and he can fight it with fortitude. Pride is a vice of inequality that is opposed to humility and fortitude. Envy prevents the knight from being just and have charity and largesse. Ire affects the memory, understanding and loving of a knight making him ignorant and acrimonious. It can be defeated with charity, abstinence and patience. The seven deadly sins can be overcome with moderation or temperance. Among the habits of a knight, Llull includes hearing mass, worshipping and fearing God, using fine words, having fine clothes and harness, taking good care of his horse, as well as using reason and discretion and a love of the common good. Knighthood does not reside in material possession but in good training of the spirit.

\section{Section VII: On the Honor that Must be Paid to the Knight}

God and the common people have honored the knight because this profession is necessary for the government of the world. The king, the prince and the lord of the land must be knights. Knighthood is endowed with seigneury and with freedom and should be loved for the goodness it produces and feared for its strength. The lord must pay honor to the knight for in so doing he increases his own honor. The knight's wife must be treated with honor and she herself must behave honorably. Knights must honor themselves and their peers. The Book of Chivalry is finished and the author promises to write a Book of Clergy. 


\section{Apéndice II}

Y cuanto a lo primero, que es proceder por las causas que hacen yerro los que mal las tratan, fundo la primera por tal razón: todas las cosas hechas por la mano de Dios son buenas necesar iamente, que según el obrador han de ser las obras: pues siendo las mujeres sus criaturas, no solamente a ellas ofende quien las afea, mas blasfema de las obras del mismo Dios.

La segunda causa es porque delante de él y de los hombres no hay pecado más abominable ni más grave de perdonar que el desconocimiento, ¿pues cuál lo puede ser mayor que desconocer el bien que por Nuestra Señora nos vino y nos viene? Ella nos libró de pena y nos hizo merecer la gloria, ella nos salva, ella nos sostiene, ella nos defiende, ella nos guía, ella nos alumbra: por ella, que fue mujer, merecen todas las otras corona de alabanza.

La tercera es porque a todo hombre es defendido según virtud, mostrarse fuerte contra lo flaco, que si por ventura los que con ellas se deslenguan pensasen recibir contradicción de manos, podría ser que tuviesen menos libertad en la lengua.

La cuarta es porque no puede ninguno decir mal de ellas sin que a sí mismo se deshonre, porque fue criado y traído en entrañas de mujer y es de su misma sustancia, y después de esto por el acatamiento y reverencia que a las madres deben los hijos.

La quinta es por la desobediencia de Dios, que dijo por su boca que el padre y la madre fuesen honrados y acatados, de cuya causa los que en las otras tocan merecen pena.

La sexta es porque todo noble es obligado a ocuparse en actos virtuosos, así en los hechos como en las hablas, pues si las palabras torpes ensucian la limpieza, muy a peligro de infamia tienen la honra de los que en tales pláticas gastan su vida.

La séptima es porque cuando se estableció la caballería, entre las otras cosas que era tenido a guardar el que se armaba caballero era una que a las mujeres guardase toda reverencia y honestidad, por donde se conoce que quiebra la ley de nobleza quien usa el contrario de ella.

La octava es por quitar de peligro la honra: los antiguos nobles tanto adelgazaban las cosas de bondad y en tanto la tenían que no habían mayor miedo de cosa que de memoria culpada: lo que no me parece que guardan los que anteponen la fealdad de la virtud, poniendo mácula con su lengua en su fama, que cualquiera se juzga lo que es en lo que habla.

La novena y muy principal es por la condenación del alma: todas las cosas tomadas se pueden satisfacer, y la fama robada tiene dudosa la satisfacción, lo que más cumplidamente determina nuestra fe. 
La decena es por excusar enemistad: los que en ofensa de las mujeres despenden el tiempo, hácense enemigos de ellas y no menos de los virtuosos, que como la virtud y la desmesura diferencian en propiedad, no pueden estar sin enemiga.

La oncena es por los daños que de tal acto malicioso se recrecía, que como las palabras tienen licencia de llegar a los oídos rudos tan bien como a los discretos, oyendo los que poco alcanzan las fealdades dichas de las mujeres, arrepentidos de haberse casado, danles mala vida o vanse de ellas, o por ventura las matan.

La docena es por las murmuraciones que mucho se deben temer, siendo un hombre infamado por difamador en las plazas, en las casas y en los campos, y dondequiera es retratado su vicio.

La trecena es por razón del peligro, que cuando los maldicientes que son habidos por tales, tan odiosos son a todos, que cualquiera les es más contrario, y algunas por satisfacer a sus amigas, puesto que ellas no lo pidan ni lo quieran, ponen las manos en los que en todas ponen la lengua.

La catorcena es por la hermosura que tienen, la cual es de tanta excelencia que, aunque cupiesen en ellas todas las cosas que los deslenguados les ponen, más hay en una que loar con verdad que no en todas que afear con malicia.

La quincena es por las grandes cosas de que han sido causa: de ellas nacieron hombres virtuosos que hicieron hazañas de digna alabanza; de ellas procedieron sabios que alcanzaron a conocer qué cosa era Dios, en cuya fe somos salvos; de ellas vinieron los inventivos que hicieron ciudades, fuerzas y edificios de perpetua excelencia; por ellas hubo tan sutiles varones que buscaron todas las cosas necesarias para sustentación del linaje humanal.

Da Leriano veinte razones por qué los hombres son obligados a las mujeres

Tefeo: pues has oído las causas por que sois culpados tú y todos los que opinión tan errada seguís, dejada toda prolijidad, oye veinte razones por donde me proferí a probar que los hombres a las mujeres somos obligados. De las cuales la primera es porque a los simples y rudos disponen para alcanzar la virtud de la prudencia, y no solamente a los torpes hacen discretos, mas a los mismos discretos más sutiles, porque si de la enamorada pasión se cautivan, tanto estudian su libertad, que avivando con el dolor el saber, dicen razones tan dulces y tan concertadas que alguna vez de compasión que les han se libran de ella. Y los simples, de su natural inocentes, cuando en amar se ponen entran con rudeza y hallan el estudio del sentimiento tan agudo que diversas veces salen sabios, de manera que suplen las mujeres lo que naturaleza en ellos faltó.

La segunda razón es porque de la virtud de la justicia tan bien nos hacen suficientes que los penados de amor, aunque desigual tormento reciben, hanlo por descanso, justificándose porque justamente padecen. Y no por sola esta causa nos hacen gozar de esta virtud, mas por otra tan natural: los firmes enamorados, para abonarse con las que sirven, buscan todas las formas que pueden, de cuyo deseo viven justificadamente sin exceder en cosa de toda igualdad por no infamarse de malas costumbres. 
La tercera, porque de la templanza nos hacen dignos, que por no serles aborrecibles, para venir a ser desamados, somos templados en el comer, en el beber y en todas las otras cosas que andan con esta virtud. Somos templados en el habla, somos templados en la mesura, somos templados en las obras, sin que un punto salgamos de la honestidad.

La cuarta es porque al que fallece fortaleza se la dan, y al que la tiene se la acrecientan: hácennos fuertes para sufrir, causan osadía para cometer, ponen corazón para esperar. Cuando a los amantes se les ofrece peligro se les apareja la gloria, tienen las afrentas por vicio, estiman más la alabanza de la amiga que el precio del largo vivir. Por ellas se comienzan y acaban hechos muy hazañosos, ponen la fortaleza en el estado que merece. Si les somos obligados, aquí se puede juzgar.

La quinta razón es porque no menos nos dotan de las virtudes teologales que de las cardinales dichas. Y tratando de la primera, que es la fe, aunque algunos en ella dudasen, siendo puestos en pensamiento enamorado creerían en Dios y alabarían su poder, porque pudo hacer a aquella que de tanta excelencia y hermosura les parece. Junto con esto los amadores tanto acostumbran y sostienen la fe, que de usarla en el corazón conocen y creen con más firmeza la de Dios. Y porque no sea sabido de quien los pena que son malos cristianos, que es una mala señal en el hombre, son tan devotos católicos, que ningún apóstol les hizo ventaja.

La sexta razón es porque nos crían en el alma la virtud de la esperanza, que puesto que los sujetos a esta ley de amores mucho penen, siempre esperan: esperan en su fe, esperan en su firmeza, esperan en la piedad de quien los pena, esperan en la condición de quien los destruye, esperan en la ventura. Pues quien tiene esperanza donde recibe pasión, ¿cómo no la tendrá en Dios, que le promete descanso? Sin duda haciéndonos mal nos aparejan el camino del bien, como por experiencia de lo dicho parece.

La séptima razón es porque nos hacen merecer la caridad, la propiedad de la cual es amor: esta tenemos en la voluntad, esta ponemos en el pensamiento, esta traemos en la memoria, esta firmamos en el corazón... Y como quiera que los que amamos la usemos por el provecho de nuestro fin, de él nos redunda que con viva contrición la tengamos para con Dios, porque trayéndonos amor a estrecho de muerte, hacemos limosnas, mandamos decir misas, ocupámosnos en caritativas obras porque nos libre de nuestros crueles pensamientos. Y como ellas de su natural son devotas, participando con ellas es forzado que hagamos las obras que hacen.

La octava razón, porque nos hacen contemplativos, que tanto nos damos a la contemplación de la hermosura y gracias de quien amamos, y tanto pensamos en nuestras pasiones, que cuando queremos contemplar la de Dios, tan tiernos y quebrantados tenemos los corazones que sus llagas y tormentos parece que recibimos en nosotros mismos, por donde se conoce que también por aquí nos ayudan para alcanzar la perdurable holganza.

La novena razón es porque nos hacen contritos, que como siendo penados pedimos con lágrimas y suspiros nuestro remedio, acostumbrados en aquello, yendo a confesar nuestras culpas, así gemimos y lloramos que el perdón de ellas merecemos. 
La decena es por el buen consejo que siempre nos dan, que a las veces acaece hallar en su presto acordar lo que nosotros cumple largo estudio y diligencia buscamos. Son sus consejos pacíficos sin ningún escándalo: quitan muchas muertes, conservan las paces, refrenan la ira y aplacan la saña. Siempre es muy sano su parecer.

La oncena es porque nos hacen honrados: con ellas se alcanzan grandes casamientos con muchas haciendas y rentas. Y porque alguno podría responderme que la honra está en la virtud y no en la riqueza, digo que tan bien causan lo uno como lo otro. Pónennos presunciones tan virtuosas que sacamos de ellas las grandes honras y alabanzas que deseamos, por ellas estimamos más la vergüenza que la vida, por ellas estudiamos todas las obras de nobleza, por ellas las ponemos en la cumbre que merecen.

La docena razón es porque apartándonos de la avaricia nos juntan con la libertad, de cuya obra ganamos las voluntades de todos, que como largamente nos hacen depender lo que tenemos, somos alabados y tenidos en mucho amor, y en cualquier necesidad que nos sobrevenga recibimos ayuda y servicio. Y no sólo nos aprovechan en hacernos usar la franqueza como debemos, mas ponen lo nuestro en mucho recaudo, porque no hay lugar donde la hacienda esté más segura que en la voluntad de las gentes.

La trecena es porque acrecientan y guardan nuestros haberes y rentas, las cuales alcanzan los hombres por ventura y consérvanlas ellas con diligencia.

La catorcena es por la limpieza que nos procuran, así en la persona como en el vestir, como en el comer, como en todas las cosas que tratamos.

La quincena es por la buena crianza que nos ponen, una de las principales cosas de que los hombres tienen necesidad. Siendo bien criados usamos la cortesía y esquivamos la pesadumbre, sabemos honrar los pequeños, sabemos tratar los mayores. Y no solamente nos hacen bien criados, mas bien quistos, porque como tratamos a cada uno como merece, cada uno nos da lo que merecemos.

La razón dieciséis es porque nos hacen ser galanes: por ellas nos desvelamos en el vestir, por ellas estudiamos en el traer, por ellas nos ataviamos de manera que ponemos por industria en nuestras personas la buena disposición que naturaleza algunos negó. Por artificio se enderezan los cuerpos, puliendo las ropas con agudeza, y por el mismo se pone cabello donde fallece, y se adelgazan o engordan las piernas si conviene hacerlo. Por las mujeres se inventan los galanes entretales, las discretas bordaduras, las nuevas invenciones. De grandes bienes por cierto son causa.

La diecisiete razón es porque nos conciertan la música y nos hacen gozar de las dulcedumbres de ella: ¿por quién se sueñan las dulces canciones?, ¿por quién se cantan los lindos romances?, ¿por quién se acuerdan las voces?, ¿por quién se adelgazan y sutilizan todas las cosas que en el canto consisten? 
La dieciochena, es porque crecen las fuerzas a los braceros, la maña a los luchadores, y la ligereza a los que voltean, corren, saltan y hacen otras cosas semejantes.

La diecinueve razón es porque afinan las gracias: los que, como es dicho, tañen y cantan por ellas, se desvelan tanto, que suben a lo más perfecto que en aquella gracia se alcanzan. Los trovadores ponen por ellas tanto estudio en lo que trovan, que lo bien dicho hacen parecer mejor, y en tanta manera se adelgazan, que propiamente lo que sienten en el corazón ponen por nuevo y galán estilo en la canción, invención o copla que quieren hacer.

La veintena y postrimera razón es porque somos hijos de mujeres, de cuyo respeto les somos más obligados que por ninguna razón de las dichas ni de cuantas se puedan decir. 


\section{Bibliografía}

Alemany, Rafael, \& Josep-Lluís Martos (1998) «Llull en el Tirant lo Blanc: entre la reescriptura i la subversió.» In Actes de l'Onzé Col loqui Internacional de Llengua i Literatura Catalanes, Barcelona, Abadia de Montserrat, I, 129-142.

Alfonso X. P. Sánchez-Prieto Borja, Rocío Díaz Moreno, Elena Trujillo Belso (eds.) Las Siete Partidas. Alfonso X el Sabio. Edición de textos alfonsíes en REAL ACADEMIA ESPAÑOLA: Banco de datos (CORDE) [on-line]. Corpus diacrónico del español. http://www.rae.es

Aguilar i Montero, Miquel (2010) «El Llibre de l'Orde de Cavalleria en el context sociocultural medieval», Tirant, 13, pp. 5-14.

Aurell i Cardona, Martí (1987) «Chevaliers et chevalerie chez Raymond Lulle.» In Raymond Lulle et le Pays d'Oc, Tolosa, Privat, pp. 141-168.

Blake, N.F. (1990) William Caxton and English Literary Culture, London, Hambledon.

Blair, Claude (1958) European Armour circa 1066 to circa 1700, London, B.T. Batsford.

Bohigas, Pere (ed.) (1947) Tractats de cavalleria. Barcelona, Barcino.

Carreras y Artau, Tomás (1934) «L'espirit cavalleresc en la producción lul liana», La Nostra Terra, n. 7, pp. 381-389.

Cavalleria, Oliver (1958) «El «Llibre del Orde de Cavalleria» de Ramón Llull y el «De laude novae militiae» de San Bernardo», Estudis Lulianos, n. 2, pp. 175-186.

Charny, Geoffroi (2005) A Knight's Own Book of Chivalry (Elspeth Kennedy trans.; Richard Kaeuper intr.), Philadelphia, UP.

(1996) The Book of Chivalry of Geoffroi de Charny. Text, Context, and Translation (Elspeth Kennedy trans. Richard W. Kaeuper intr.), Philadelphia, University of Pennsylvania Press.

Clavería, Carlos (1942) «Sobre la traducción inglesa del Libre del orde de cavalleria de Ramón Llull», Analecta Sacra Tarraconensia, n. 15, pp. 65-74.

Cortijo Ocaña, Antonio (2001) La evolución genérica de la ficción sentimental, London, Tamesis.

Cosman, Madelaine Pelner (1965) The Education of the Hero in Arthurian Romance, Chapel Hill, University of North Carolina Press.

Costa, Ricardo da (2005) «A noção de pecado e os sete pecados capitais no Livro das Maravilhas (1288-1289) de Ramon Llull.» In R. de Oliveira Andrade Filho (org.) Estudos en Homenagem ao Professor Daniel Valle Ribeiro, Sanata de Parnaíba, SP, Editoria Solis, pp. 425-432.

(1997) «Ramon Llull (1232-1316) e o modelo cavaleiresco ibérico: el Libro del Orden de la Caballería), Medievalia. Textos e Estudos n. 11/12, pp. 231-252.

- «A cavaleria perfeita e as virtudes do bom cavaleiro no Livro da Ordem de Cavalaria (1275), de Ramon Llull.» 
http://www.ricardocosta.com/artigo/cavalaria-perfeita-e-virtudes-do-bom-cavaleiro-no-livroda-ordem-de-cavalaria-1275-de-ramon.

Domínguez Reboiras, F. (1996) «El proyecto luliano de predicación cristiana». In Constantes y fragmentos del pensamiento luliano. Actas del simposio sobre Ramon Llull en Trujillo, 17-20 septiembre 1994. In F. Domínguez \& J. Salas (eds.) «Sonderdruck aus Beiheft zur Iberoromania 12.» Tubinga: De Gruyter, pp. 117-132.

(1995) «Raimundio Lulio y el ideal mendicante. Afinidades y divergencias.» In Aristotelica et lulliana magistro doctissimo Charles H. Lobr septuagessimum annum feliciter agenti dedicata. F. Domínguez Reboiras, T. Pindl \& P. Walter eds. The Haye: Abbatia S. Petri, pp. 377-413.

Fallows, Noel (2010) Jousting in Medieval and Renaissance Iberia, Woodbridge, Boydell Press.

Genovart Servera, G. (1982) «El Cavaller i el Vell Savi. (Imatges i símbols de la pedagogía lul liana)», Estudis Baleàrics 2.4, pp. 59-75.

Lloret, Albert. «Modelos jurídicos y reformas sociales en el Llibre de l'orde de cavalleria de Ramón Llull.» La corónica 35.1 (2006): 171-190.

Llull, R. (1483-1485) Book of the Ordre of Chivalry or Knyghthode, (William Caxton tr.), Westminster, W. Caxton.

- (2015) The Book of the Order of Chivalry / Llibre de l'Ordre de Cavalleria / Libro de la Orden de Caballeria (Cortijo, Antonio, tr.), IVITRA Research in Linguistics and Literature, 81, Amsterdam, John Benjamins. benjamins.com/\#catalog/books/ivitra.8/main

- (en prensa) Libro de la caballería/Llibre de l'orde de la cavalleria (Butiñá, Julia, tr.), Madrid, Atenea.

Lourie, Elena (1996) «A Society Organized for War: Medieval Spain», Past and Present, n. 35, pp. 54-76.

Maíz Chacín, Jorge (2005) «La argumentación filosófica del caballero medieval. El modelo e ideal luliano en el Libre del Orde de Cavaleria», Mirabilia, n. 5, pp. 111-141.

Malcolm, Barber (1994) The New Knighthood. A History of the Order of the Temple, Cambridge: UP.

Martos Sánchez, Josep Lluís (2001) Les proses mitologiques de Joan Roís de Corella. Alacant \& Barcelona: Institut Universitari de Filologia Valenciana, Publicacions de l'Abadia de Montserrat.

- (2000) «Ramon Llull y el Libre de l'orde de cavalleria: un tratado de caballería entre el ars y el roman». In A. Deyermond (ed.) Proceedings of the Tenth Colloquium, London: Department of Hispanic Studies, Queen Mary \& Westfield College, pp. 85-98.

Martorell, Joanot (2004) Tirant lo Blanch, Albert Hauf. (ed.), València, Editorial Tirant lo Blanc.

—_. (1990) Tirant lo Blanc i altres escrits de Joanot Martorell, Martí de Riquer (ed.), Barcelona, Ariel.

Martorell, Joanot \& Martí Joan de Galba(?) (1990) Tirant lo Blanch, Albert G. Hauf \& Vicent Josep Escartí (eds.), València: Conselleria de Cultura. 2 vols. 
Morey Mora, Guillermo (1962) «Puntos de relación entre la Historia del ingenioso bidalgo D. Quijote de la Mancha y el Libre de Orde de Cavalleria de Ramón Llull», Estudis Lulians, n. 6, pp. 117-126.

Nunes Lemos, Tatyana (2008) «O nobre a o 'pobre' cavaleiro: duas perspectivas lulianas», Mirabilia, n. 8, pp. 205-220.

Oliver, Antonio (1958) «El Libre del Orde de Cavalleria de Ramón Llull y el De Laude Novae Militiae de San Bernardo», Estudis Lulians, n. 2, pp. 175-186.

Otaka, Yorio (1978) «Ystème verbal du Libre de l'Orde de Cavalleria de Ramon Llull», Cultural Neolatina, n. 38, pp. 167-198.

Piemontese-Ramos, Luisa (1990) «Libre del Orde de Cavaleyria: Fashion and Fiction», Catalan Review, n. 4, pp. 347-355.

Piña Homs, Román (1984) Alfonso X el Sabio y Ramón Llull: su concepción de la justicia y del oprden social, Palma de Mallorca, UP.

Powers, James F. (1988) A Society Organized for War: The Iberian Municipal Militias in the Central Middle Ages, Berkeley, UP.

Ramos, Rafael (1995) «Tirant lo Blanc, Lancelot du Lac y el Llibre de l'orde de cavalleria.» La Corónica n. 23.2, pp. $74-87$.

Rodríguez Velasco, Jesús (2010) Order and Chivalry. Knighthood and Citizenship in Late Medieval Castile, Pennsylvania, 2010.

- (2006) El debate sobre la caballería en el siglo XV: la tratadística caballeresca y el mundo caballeresco, Madrid, Siglo XXI.

San Pedro, Diego de (1995). Cárcel de amor (con la continuación de Nicolás Núñez), Carmen Parrilla (ed.) Barcelona, Crítica.

- (1985) Keith Whinnom ed. Obras completes I. Tractado de amores de Arnalte y Lucenda. Sermón, Madrid, Castalia.

Sanchis Guarner, Manuel (1968) «L'ideal cavalleresc definit per Ramon Llull», Estudis Lulians, n. 2 pp. 37-62.

Serés, Guillero (1991) «Milicia-Malicia en el Siglo de Oro: de la virtus a la cautela», Scriptura, n. 6-7, pp. 15-23.

—. (1996a) La transformación de los amantes, Barcelona, Crítica, 1996a.

- (1996b) «La ira justa y el templado amor, fundamentos de la virtus en La Galatea», Bulletin Hispanique, n. 98.1, pp. 37-54.

Sutton, Anne F., \& Livia Visser-Fuchs (1991) «Richard III's Books, XI: Ramon Lull's Order of Chivalry translated by William Caxton», The Ricardian: Journal of the Richard III Society, n. 9, pp. 110-129. 